\title{
CLINICAL INVESTIGATION OF THE VALUE OF SYNTHETIC HYALURONIDASE INHIBITORS IN RHEUMATQID ARTHRITIS
}

\author{
BY \\ L. HAHN, S. THUNE, and E. TRUEDSSON \\ From the Department of Rheumatic Diseases, University Hospital, Lund, Sweden \\ (Director: Dr. G. Edström, M.D.) \\ -(RECEIVED FOR PUBLICATION AUGUST 7, 1952)
}

The possible role of hyaluronidase in the pathogenesis of rheumatic diseases was first suggested some ten years ago (Wallenfels, 1941; Hahn, 1944), since which time the subject has received a fair amount of attention. Certain observations in the literature suggest some interrelationship between the pathological changes of the mesenchymal tissue and an imbalance of the hyaluronidase-hyaluronic acid system. In rheumatoid arthritis the viscosity of the joint exudate is lower than that of synovia in normal subjects (Robertson and others, 1940). The degree of polymerization of the hyaluronic acid in such exudate is likewise lowered (Ropes and others, 1947). It has also been shown that in rheumatoid arthritis the viscosity of the joint exudate can be increased by intra-articular injection of cortisone (Bauer, 1950; Ekman and others, 1952). The in vitro inhibitory action of the exudate on hyaluronidase is also appreciably enhanced after such an injection (Ekman and others, 1952).

While studying various substances for their effect on the enzymatic breakdown of hyaluronic acid, it was found that certain polycondensed diphenylmethane and triphenylmethane derivatives possess the power strongly to inhibit such hydrolysis in vitro (Hahn, 1952). Some of these substances were also tried in animal experiments and proved to be also strong inhibitors of hyaluronidase in vivo (FabinyiSzebehely and others, 1952).

The purpose of the present investigation was to find whether these substances might be of any value in the treatment of rheumatoid arthritis.

Synthetic Hyaluronidase Inhibitors (SHI) Tested

(1) Compound $21 \quad P$ (Polycondensed hexahydroxy-tricarboxy-triphenyl-methane). This substance is the product of simultaneous oxidation of polycondensed tetrahydroxy-dicarboxy diphenylmethane and dihydroxy benzoic acid. Its inhibitory power in vitro is 2,490 relative units (resorcinol $=1$ ). It is the most active hyaluronidase inhibitor both in vitro and in vivo hitherto described. Its oral LD50 is $>20 \mathrm{mg} . / \mathrm{g}$. in mice.

(2) Compound $7 P$ (Polycondensated tetrahydroxy- $-\vec{O}$ dicarboxy diphenyl-methane). This compound is the product of condensation of dihydroxy benzoic acid with formaldehyde under conditions favouring the formation of molecules of fairly large size. It possesses less inhibitory power than Compougece $21 \mathrm{P}$. Its oral LD50 is $10 \mathrm{mg}$./g. in mice.

(3) Compound $16 \quad P$ (Polycondensed hepta hydroxy-tricarboxy triphenyl-methane). This compound was derived from polycondensed methylenedi- $\beta$-resorcylic acid by substitution with 2.3.4-tri-o hydroxy-6-carboxy phenyl radicals in the methylene groups. The inhibitory power of this substance is $\overrightarrow{\overrightarrow{0}}$ slightly less than that of Compound $7 \mathrm{P}$ in vitro, but approximately the same in vivo. Its ora LD50 is $5.4 \mathrm{mg} . / \mathrm{g}$. in mice.

\section{Material}

The material consisted of 101 cases ( 36 males and $65 \frac{5}{3}$ females) with rheumatoid arthritis treated in this Department. Of these, 85 were in-patients and sixteen out-o patients. The ages ranged from 7 to 62 years (average 42). At the commencement of the trial the patients hado had rheumatoid arthritis for 1 to 27 years (average 8) and had been suffering from an exacerbation for 2 too 72 months (average 12). All of them showed pronounced symptoms and signs of the disease which was in an activer stage. The in-patients were receiving selective physio- $N$ therapy and 34 of them were being treated with golde compounds. Most of them were receiving salicylate. $\omega$ This treatment was stopped immediately before or soon after the commencement of the trial. As to the outeo patients, all previous medication was suspended for the duration of the trial, but no changes in regimen were? prescribed. At the beginning of the trial no tendency to abatement was demonstrable in any of the patients. 


\section{Method}

The following joint symptoms were recorded: resting pain, pain on movement, pain on weight-bearing, and tenderness to palpation. Four degrees of intensity $(0,1,2,3)$ were distinguished.

The joint signs, peri-articular swelling, capsular swelling, exudate, and impaired range of motion, were evaluated by two of us (S.T. and E.T.) together. For purposes of control, a number of cases were examined by each of us separately and our records were in good agreement. We distinguished five degrees of periarticular swelling $(0,1,2,3,4)$, three degrees of capsular swelling $(0,1,2)$, four degrees of exudate $(0,1,2,3)$, and two degrees (fair, good) of improvement in range of motion, as measured by a protractor.

Altogether 1,490 joints were examined in this way on the average four to five times. This total was made up as follows:

cervical vertebrae, 4 ; shoulders, 18;

elbows, 42;

wrists, 126;

metacarpo-phalangeal joints, 520;

lumbar vertebrae, 2.

$$
\begin{aligned}
& \text { proximal interphalangeal } \\
& \text { joints, } 360 ; \\
& \text { knees, } 146 ; \\
& \text { ankles, 82; } \\
& \text { metatarso-phalangeal } \\
& \text { joints, 190; }
\end{aligned}
$$

In the evaluation of the effect of the compounds all of the joints studied in any one patient were taken as a single joint. For each symptom and sign the averages of the values recorded for the individual joints were calculated at every examination. The values for metacarpophalangeal joints, proximal interphalangeal joints and metatarso-phalangeal joints included in the above calculation were averages of the recordings made for the five joints of the hand or foot in question.

Any difference found between the averages of the initial recordings and the averages of the final recordings was calculated as a percentage of the initial values. Decreases by 1 to 25 per cent., 26 to 50 per cent., 51 to 75 per cent. and 76 to 100 per cent. are given in the Tables as,,++++++ , and ++++ .

The following laboratory tests were carried out: Heller's test, Almén's test, urinary sediment, erythrocyte sedimentation rate, percentage of haemoglobin, counts of erythrocytes, leucocytes, eosinophilic leucocytes, and thrombocytes, differential blood count, and prothrombin index. Temperature charts were also plotted.
The substances were administered per os in 0.5-g. tablets three to six times daily. The largest dose given was $2 \mathrm{~g}$. The total daily dose varied from 3 to $10 \mathrm{~g}$.

Two inhibitors were sometimes tried in immediate succession in the same patient.

\section{Results}

(1) Compound 21 P.-Fifty subjects (39 in-patients and 11 out-patients) received Compound $21 \mathrm{P}$ daily for 3 to 111 days (average 41). In order to obtain an idea of the optimal dosage, the daily dose was varied from $4 \cdot 5$ to $10 \mathrm{~g}$. (average 7.0). Five doses of $1.5 \mathrm{~g}$. daily were found to be suitable for adults. The total amount received by a single patient varied between 23 and $738 \mathrm{~g}$. (average 284).

Altogether 751 joints were regularly studied in these fifty patients.*

In all patients the clinical effect produced was favourable. In one case the administration of the substance was interrupted after 3 days. Already within this time the regression of the pronounced symptoms and signs of the joints recorded was striking. The abatement of the joint symptoms and signs is apparent from Table I. In 36 patients in whom the initial abatement of the symptoms could be dated with certainty, it occurred within 5 days on the average. The regression of the signs was usually demonstrable within 7 days. The rate of improvement of the peri-articular swelling was usually highest during the first 2 to 3 weeks of the SHI administration.

As seen from Table I, in most of the cases no pronounced reduction of the capsular swelling was obtained. We have shown that streptochinase in combination with streptodornase, when injected intra-articularly, breaks down any fibrin clots in the joints. This disintegration of the fibrin clots and aspiration of the joint exudate reduces capsular swelling to such an extent that the capsule appears

\begin{tabular}{|c|c|c|c|c|c|c|c|c|c|}
\hline & \multirow{3}{*}{ Symptoms } & & \multicolumn{6}{|c|}{ No. of Cases } & \multirow{3}{*}{$\begin{array}{l}\text { Symptoms } \\
\text { not } \\
\text { Recorded }\end{array}$} \\
\hline & & & \multirow{2}{*}{$\begin{array}{l}\text { Initially } \\
\text { without } \\
\text { Symptoms }\end{array}$} & \multicolumn{5}{|c|}{ Improvement } & \\
\hline & & & & 0 & + & ++ & $+t+$ & $+t+t$ & \\
\hline Subjective & $\begin{array}{l}\text { Resting pain } \\
\text { Pain on movement } \\
\text { Pain on weight-bearing } \\
\text { Tenderness to palpation }\end{array}$ & $\begin{array}{l}\cdots \\
\cdots \\
\cdots\end{array}$ & $\begin{array}{r}27 \\
2 \\
7 \\
8\end{array}$ & $\begin{array}{l}2 \\
4 \\
5 \\
6\end{array}$ & $\frac{-1}{1}$ & $\begin{array}{l}2 \\
9 \\
1 \\
7\end{array}$ & $\begin{array}{r}3 \\
11 \\
14 \\
6\end{array}$ & $\begin{array}{l}16 \\
22 \\
12 \\
18\end{array}$ & $\begin{array}{r}71 \\
11 \\
4\end{array}$ \\
\hline Objective & $\begin{array}{l}\text { Peri-articular swelling } \\
\text { Capsular swelling } \\
\text { Exudate .. } \quad \ldots\end{array}$ & $\begin{array}{l}\cdots \\
\cdots \\
\cdots\end{array}$ & $\frac{-}{2}$ & $\overline{28}$ & $\begin{array}{l}3 \\
\mathbf{1} \\
\mathbf{3}\end{array}$ & $\begin{array}{r}17 \\
1 \\
7\end{array}$ & $\begin{array}{r}15 \\
12 \\
5\end{array}$ & $\begin{array}{r}14 \\
1 \\
9\end{array}$ & $\begin{array}{r}1 \\
5 \\
11\end{array}$ \\
\hline
\end{tabular}
practically normal on palpation. Therefore in some

* Since the preparation of this paper for the press another ten out-patients have received similar doses with equally good results.

TABLE I

CLINICAL INVESTIGATION OF COMPOUND 21 P (50 SUBJECTS) 
patients "capsular swelling" may be ascribed to a deposition of fibrin in the joints.

Of 43 patients with limited movement of the joints, a fair improvement in the range of motion was noted in 31 and a good improvement in five.

In eight of twelve patients, low grade fever passed off. Heller's test and Almén's test was regularly negative in all the fifty patients, and the urinary sediment, which was examined on various occasions, was always normal. This compound had no effect on the percentage of haemoglobin or on the number of erythrocytes. The E.S.R. was followed in 47 cases, in 45 of which it was increased from the beginning. A moderate decrease was observed in sixteen cases, in two of which the level returned to normal. In seven a moderate increase in E.S.R. was recorded, and in 24 no appreciable change was observed. Transient leucocytosis was noted in two of forty cases. In five of 34 patients a moderate transient increase in the total number of eosinophilic leucocytes was noted (examined ad modum RUD). These five patients had not received gold therapy. Neither the total number of thrombocytes nor the prothrombin index were affected. No appreciable change in body weight was noted.

The clinical improvement was often accompanied by a usually transient sensation of warmth, flushes, and sometimes sweating, particularly among the females Occasional looseness of stools soon passed off without any special treatment, but in two cases it was necessaty. to decrease the daily dose from initially $7 \cdot 5$ to 6 g. No other side-effects were observed.

Compound 7 P. -28 subjects (23 in-patiento 5 out-patients) received 3 to $9 \mathrm{~g}$. (average 6) of Compound $7 \mathrm{P}$ daily for 3 to 98 days (average 29 The total amount received by a single patient varieg between 18 and $732 \mathrm{~g}$. (average 178).

Altogether 423 joints were regularly studied. The effect was similar to that produced by Compoun $\$$ $21 \mathrm{P}$ but was less pronounced (Table II). In the case in which the substance was administered fom only 3 days the clinical effect was obvious. In five cases no improvement was recorded.

No side-effects were observed.

Compound 16 P.-23 subjects, all in-patients received 3 to 9 g. (average 7) of Compound $16 \mathrm{P}$ dailfy for 5 to 56 days (average 21). The total amount received by a single patient varied between 33 and 336 g. (average 137).

Altogether 316 joints were regularly studieœ The effect was similar to that produced by Compoun $21 \mathrm{P}$ but less pronounced (Table III). Improvement was recorded in every patient treated with thisi substance.

TABLE II

CLINICAL INVESTIGATION OF COMPOUND 7 P (28 SUBJECTS)

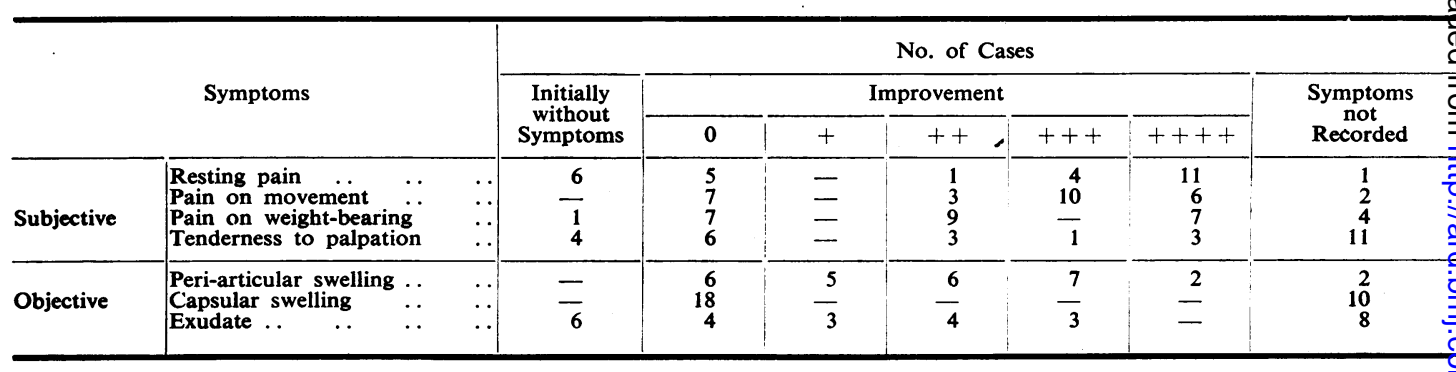

TABLE III

CLINICAL INVESTIGATION OF COMPOUND 16 P (23 SUBJECTS)

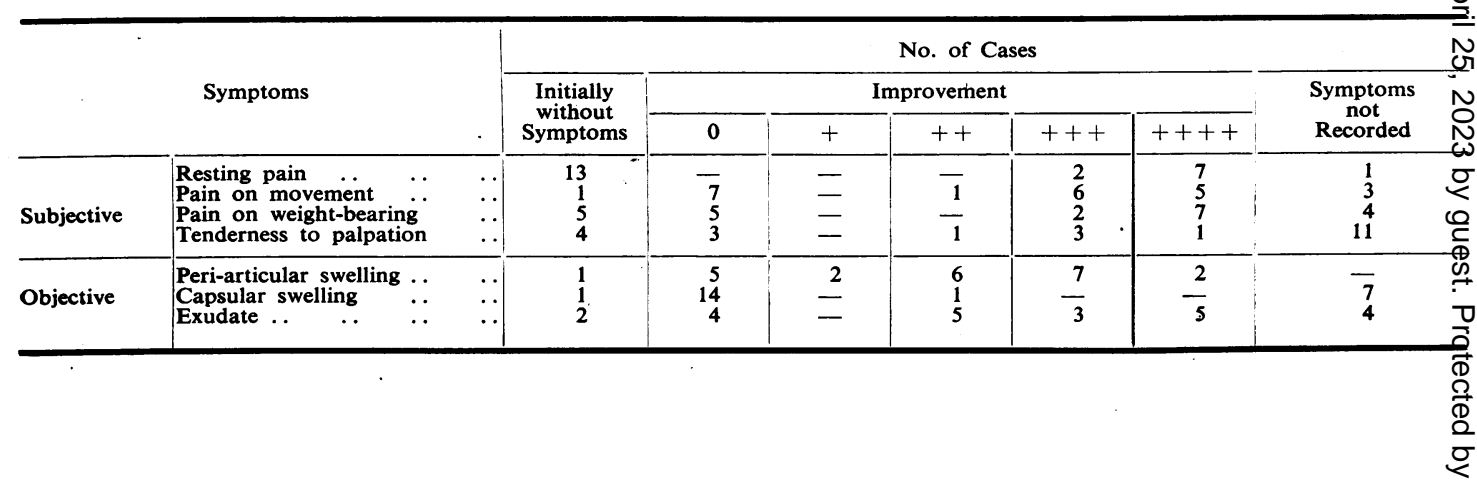


Effective doses sometimes caused severe diarrhoea that made it necessary to stop the administration of the substance.

\section{Discussion}

The material was selected in such a manner that spontaneous improvement could be excluded with reasonable certainty at the commencement of the trial. These requirements probably best fulfilled by long-standing cases, in patients suffering from a fairly long exacerbation. In our series the patients had had rheumatoid arthritis for 8 years on the average and had been suffering from an exacerbation for about 12 months.

In order to facilitate the evaluation of any differences in the condition of the joints we selected only those with striking changes, particularly with marked peri-articular swelling.

Rheumatoid arthritis often responds favourably to ordinary hospital regimen, and the initial signs of improvement usually appear within a few weeks. In our series, however, definite improvement was generally already recorded within 7 days.

Of the patients who received Compound $21 \mathrm{P}$, sixteen were also treated simultaneously with gold compounds. No difference was observed between the clinical results obtained in the patients receiving gold compounds and those in the rest of the group.

Compounds $21 \mathrm{P}$ and $7 \mathrm{P}$ were tried on both inpatients and out-patients and produced equally good results in both. Compound $16 \mathrm{P}$ was not administered to out-patients. The out-patients received no other kind of therapy and no changes in regimen were prescribed.

Suspension of salicylate administration at the start of the trial was usually followed by a transient increase in the joint pain. This is because the compounds tested have practically no analgesic effect. The subsequent marked decrease in the severity of the joint symptoms recorded after a few days' administration of the compounds must be interpreted as an improvement in the condition of the joint. This gave fairly accurate information about the onset of the effect of the compounds tested on the joint symptoms. Salicylate was a source of comfort to most of the patients. A few days after this drug was replaced by the SHI the joints became less painful than they had been during the previous salicylate administration. Although the patients themselves also noticed a decrease in the swelling of the joints, they did not feel quite satisfied. It is suggested that this may be ascribed to some euphoric effect possessed by salicylate but not by the substances tried.

Observations made in the present investigation suggested the following conclusions:
(1) Compound $21 \mathrm{P}$ produces the most favourable clinical results and practically no side-effects.

(2) Compound $7 \mathrm{P}$ is the least effective clinically and is accompanied by practically no side-effects.

(3) Compound $16 \mathrm{P}$ when given in effective therapeutic doses produces severe diarrhoea.

It is, of course, too early to say whether the results obtained will last for any length of time without further medication or whether improvement will continue. Further investigations are in progress.

\section{Summary}

Three synthetic hyaluronidase inhibitors: polycondensed hexahydroxy-tricarboxy-triphenylmethane (Compound $21 \mathrm{P}$ )

polycondensed tetrahydroxy-dicarboxy-diphenylmethane (Compound $7 \mathrm{P}$ )

polycondensed heptahydroxy-tricarboxy-triphenylmethane (Compound $16 \mathrm{P}$ )

were investigated for their clinical value in rheumatoid arthritis.

The material consisted of 101 cases of active rheumatoid arthritis (85 in-patients, 16 out-patients). Symptoms and signs in altogether 1,490 joints were recorded four to five times during the trial. All three compounds had similar pronounced beneficial effects on the joint symptoms and signs.

Compound $21 \mathrm{P}$, which proved to be the strongest hyaluronidase inhibitor in vitro and in vivo, produced the strongest clinical reaction and was attended by practically no side-effects.

Our thanks are due to Dr. Gunnar Edström for numerous facilities put at our disposal.

\section{REFERENCES}

Bauer, W. (1950). See discussion following paper by Freyberg, R. H., Patterson, M., Adams, C. H., Durivage, J., and Traeger, C. H. (1950). Annals of the Rheumatic Diseases, 9, 394.

Ekman, B., Thune, S., and Truedsson, E. (1953). Scand. J. Lab. clin. Invest. In the press.

Fabinyi-Szebehely, M., Hahn, L., and Szebehely, J. (1952). Brit. J. Pharm. Ther. In the press.

Hahn, L. (1944). Fermentforschung, 17, 417.

(1952). Nature, Lond., 170. In the press.

Robertson, W., Ropes, M. W., and Bauer, W. (1940). J. biol. Chem., 133, 261 .

Ropes, M. W., Robertson, W., Rossmeisl, E. C., Peabody, R. B., and Bauer, W. (1947). Acta med. scand., Suppl. 196, 700.

Wallenfels, K. (1941). Angew. Chem., 54, 234.

Recherches cliniques sur la valeur des inhibiteurs synthétiques de la hyaluronidase dans l'arthrite rhumatismale

RÉSUMÉ

On étudia, du point de vue de leur valeur clinique dans l'arthrite rhumatismale, les trois suivants inhibiteurs synthétiques de la hyaluronidase:

hexahydroxy-tricarboxy-triphénylméthane polycondensé (Composé $21 \mathrm{P}$ ),

tetrahydroxy-dicarboxy-diphénylméthane polycondensé (Composé 7 P),

heptahydroxy-tricarboxy-triphénylméthane polycondensé (Composé 16 P). 
Le matériel consistait en 101 cas d'arthrite rhumatismale active (85 malades hospitalisés et 16 externes). $\mathrm{Au}$ cours des recherches on prit note à quatre ou cinq reprises de signes et de symptômes dans 1.490 articulations. L'effet sur les signes et symptômes articulaires fut favorable et similaire pour les trois composés.

Le Composé $21 \mathrm{P}$, qui s'avéra l'inhibiteur le plus fort de la hyaluronidase in vitro et in vivo, donna aussi la plus forte réaction clinique, sans virtuellement s'accompagner d'effets secondaires.

Investigación clínica sobre el valor de los inhibidores sintéticos de la hialuronidase en la artritis reumatoide SUMARIO

Los tres siguientes inhibidores sintéticos de la hialuronidase fueron estudiados para determinar su valor en la artritis reumatoide: hexahidroxi-tricarboxi-trifenilmetano sado (Compuesto $21 \mathrm{P}$ ),

tetrahidroxi-dicarboxi-difenilmetano policondensado (Compuesto $7 \mathrm{P}$ ),

heptahidroxi-tricarboxi-trifenilmetano policonden sado (Compuesto $16 \mathrm{P}$ ).

El material consistió de 101 casos de artritis reumatoidę activa (85 enfermos hospitalizados y 16 externos) Durante la investigación se tomó nota cuatro o cincos veces de los signos y síntomas en un total de 1,490B articulaciones. Los tres compuestos ejercieron un efecton similar y muy favorable sobre los signos y síntomas.

El Compuesto $21 \mathrm{P}$, que se mostró el inhibidor más fuerte de la hialuronidase in vitro e in vivo, produjo también la más fuerte reacción clínica sin virtualmente darlugar a efectos secundarios. 